\title{
Cheese whey exploitation in Brazil: a questionnaire survey
}

\author{
Monika B. TRINDADE ${ }^{1}$, Bruna C. V. SOARES ${ }^{1}$, Hugo SCUDINO², Jonas T. GUIMARÃES ${ }^{2}$, Erick A. ESMERINO², \\ Mônica Q. FREITAS' ${ }^{2}$, Tatiana C. PIMENTEL ${ }^{3}$, Marcia Cristina SILVA ${ }^{1}$, Simone L. Q. SOUZA ${ }^{1}$, Rafael B. ALMADA ${ }^{1}$, \\ Adriano G. CRUZ ${ }^{1 *}$
}

\begin{abstract}
This study aimed to carry out a diagnosis of the cheese whey exploitation by the Brazilian dairy industry using a questionnaire survey. The dairy industries $(\mathrm{n}=100)$ were mainly from Southeast $(55 \%)$ and South $(25 \%)$ regions and supervised by the Federal Inspection System (80\%). Most of them produced (67\%) and processed (60\%) sweet cheese whey, using it in whey dairy beverages $(60 \%)$, Ricotta (20\%), whey concentrate (15\%), and milk blends (5\%), which were resold for supermarkets $(53 \%)$ or industries $(20 \%)$. However, $27 \%$ of the industries discard whey in the effluent treatment system or use as animal feed, suggesting a market for using this by-product.
\end{abstract}

Keywords: cheese whey; exploitation; Brazil; survey.

Practical Application: Indicate the main practices used in cheese whey handling by the Brazialian dairy using.

\section{Introduction}

Cheese is a well known and popular dairy food produced around the world, and cheese processing involves several steps, including the addition of rennet, lactic acid and/or lactic acid cultures, coagulation, cutting the curd, syneresis, and storage (Brighenti et al., 2018). Cheese consumption in Brazil corresponds to $5.9 \mathrm{~kg} / \mathrm{hab} /$ year, with a growth of $68.8 \%$ in the last 6 years (Gomes et al., 2017). Despite the changes in eating habits and consumption trends of the population, Mozzarella, Prato cheese, Requeijão, and Minas cheese are the varieties most preferred by the Brazilian consumers, thus most produced in the country (Gomes et al., 2017). In this context, regardless of the type of cheese, a large amount of effluent has been generated by the cheese industry (Carvalho et al., 2013).

Cheese whey is the main by-product generated by the cheese industry and is called sweet whey when coming from rennet-coagulated cheese $(\mathrm{pH}$ 6-6.8) and acid whey when the coagulation is performed by both the addition of acids or fermentative processes $(\mathrm{pH}<6)(B r a s i l, 2012$; Yadav et al., 2015). The physicochemical composition of whey depends on several factors, including the cheese making processes, the type of milk used (bovine, goat, or sheep), environmental conditions (period of the year), and animals (nutrition and stage of lactation) (Kelly, 2019a). The disposal of untreated whey in the environment can lead to high oxygen demand, waterproofing, eutrophication, and toxicity (Mann et al., 2019). It can be used for a variety of purposes, such as biological treatments (aerobic and anaerobic digestion), fermentation (ethanol, hydrogen or lactic acid), membrane separation (protein concentrates or lactose production), soil fertilization, among others (Ahmad et al., 2019; Kelly, 2019a, b;
Uduwerella et al., 2018). The disposal in soil is a major cause for environmental concern, once it affects its physicochemical characteristics (Yadav et al., 2015). The noblest form of use of whey is as an ingredient in food and dairy products, as it is a low-cost and high-nutrient raw material (Smithers, 2015; Mann et al., 2019).

The use of cheese whey is of industrial interest, due to the large amount produced, availability of nutrients, besides being a potent environmental pollutant if discarded untreated in the environment (Guimarães et al., 2018, 2019). In this sense, this study aimed to perform a diagnosis of the use of cheese whey in the Brazilian dairy processors.

\section{Materials and methods}

The research method consisted of a combination of exploratory analysis and quantitative and qualitative analysis, involving the quality assurance sector belonging to 100 dairy industries from various regions of the country, registered in the Brazilian inspection systems (SIF, SIE, and SIM). The sample $(\mathrm{n}=100)$ can be considered a convenience sample, which is used to understand a situation in general (Felicio et al., 2013). The research involved the following steps: (a) prior telephone contact with the production unit explaining the purpose of the study, which was discussed with the person responsible for the production sector; (b) providing a questionnaire to the dairy industry that agreed to participate in the research; and (c) returning the questionnaire with the responses. The industry anonymity was guaranteed. 
The questionnaire consisted of questions related to the production capacity (L/day), type of whey (sweet or acid), inspection regime (municipal, state, or federal) and information on the use of whey, including the volume used, main suppliers, quality control, destination (internal processing, sale, disposal and/or donation), and main distribution channels of the processed products (supermarkets, restaurants, industries, and others).

Data were analyzed using descriptive analysis, with numerical variables represented by the frequencies (absolute and relative to the total sample size) of the cases. Thus, the analysis consisted of organizing, summarizing, characterizing, and interpreting the numerical data collected, as also performed by Felicio et al. (2013).

\section{Results and discussion}

Of the 100 dairy industries studied, $80 \%$ were under federal supervision (SIF), 13\% under state inspection (SIE), and 7\% under municipal inspection (SIM), and located in the Southeast (55\%), South (25\%), Midwest (10\%), Northeast (10\%), and North (5\%) of the country. Of the total volume of milk processed $(28,207$ thousand liters/day), 5,782 thousand liters of whey were generated per day.

Concerning the effluent treatment, $100 \%$ of the dairy industries claimed to have the operating system, that is, they were all adapted to comply with the environmental legislation. Of the total volume of milk processed (28,207 thousand liters/day), 5,782 thousand liters of whey were generated per day.

Regarding the use of whey, $60 \%$ of the dairy industries mentioned that whey was fully utilized, $13 \%$ reported a partial use, and $27 \%$ mentioned not using whey to make new products, thus discarding the total whey produced $(4,208$ thousand liters per month) in the effluent treatment system or donating for animal feed.

Figure 1 presents the results of the questionnaire concerning the type of whey produced and the form of use. From the 100 dairy industries, $67 \%$ generated and/or used sweet whey, 27\% acid whey, and $6 \%$ generated both types of whey (Figure 1) while the main distribution channels of whey-containing products reported were. to supermarkets (53\%), food industry (20\%), with $27 \%$ of whey is discarded (Figure 2).

Table 1 shows the main whey-containing products manufactured by the Dairy Industrues. Whey beverages is the most dairy product manufactured using whey $(60 \%)$, followed by Ricotta cheese (20\%) and whey concentrate (10\%). A small portion (5\%) reports the use of whey as ingredient for dairy mixture, composed of whey and milk power. Most of the dairy industries $(60 \%)$ reported that whey produced or purchased from other dairy industry was used in its entirety. Of these, $70 \%$ used whey from their own manufacture to produce other products, while 30\% reported purchasing whey from other suppliers. These reports represent 1,927 thousand liters of whey per day, which is purchased from other dairy industries and used for the development of new products.

This study aims to investigate the exploitation of cheese whey in Brazil through a questionnaire survey. Most of the dairy industries of the present study can commercialize their products throughout the national territory, once they were registered in the inspection and registration systems. Indeed, of total amount of cheese produced in Brazil, $68 \%$ are considered commodities, such as mozzarella, Prato cheese, and Requeijão processed cheese, mostly produced by enzymatic coagulation (Zoccal, 2016), corroborating the prevalence of sweet whey as a by-product.

A previous study has reported that about $40 \%$ whey produced in Brazil was inappropriately discarded, mainly by small and medium-sized companies (Marquardt et al., 2012), indicating an evolution in relation to this aspect. In fact, whey is a harmful waste to the environment and can cause great impact and damage to the fauna and flora, once its Biochemical Oxygen Demand

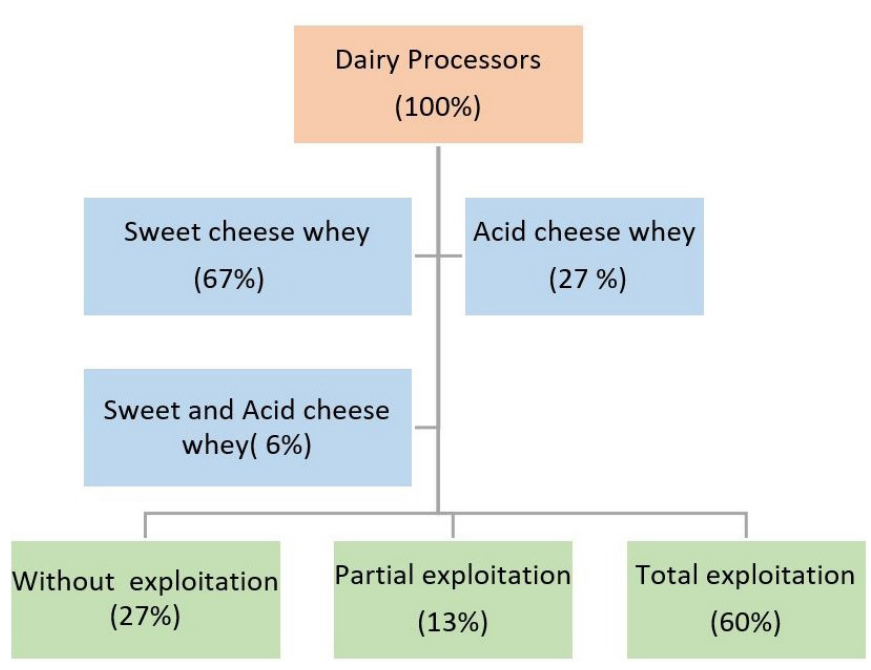

Figure 1. Types of whey and forms of exploitation by the Brazilian dairy industry.

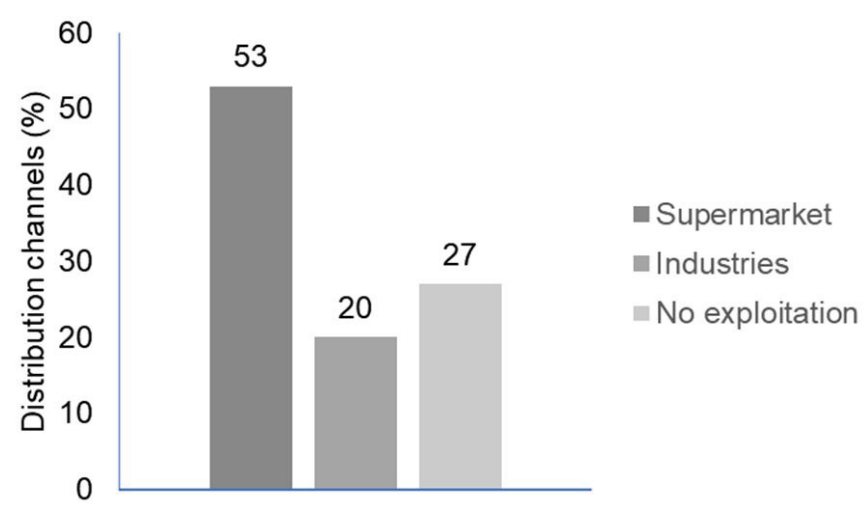

Figure 2. Distribution channels of the products with whey.

Table 1. Use of chese whey in dairy products by the Brazilian Dairy Industry.

\begin{tabular}{lc}
\hline \multicolumn{1}{c}{ Type of product } & $\%$ \\
\hline Whey beverage & 60 \\
Ricota cheese & 20 \\
Whey concentrate & 15 \\
Dairy mixture (whey and milk powder) & 5 \\
\hline
\end{tabular}


(BOD) is very high (Nunes et al., 2018). Our results suggest an improvement in awareness regarding the negative impact caused by the whey disposal in the environment. It was reported that relatively high volume of whey is discharged, that it can brings several environmental damages and depletion of the effluent treatment system if not treated properly (Nunes et al., 2018).

The use of whey in animal feed is more advantageous in monogastric (swine) animals and represents a form of use with little or no processing need, and it is a strategy to improve weight gain and reduce production costs (Palmieri et al., 2017; Lutz et al., 2017). The dairy industries with partial use of whey (13\%) reported a number of reasons for not using this by-product, including the distance from the small production units to a dairy industry with a capacity for utilization, the cost of transportation, the care of small producers with the quality of whey generated, among others.

Cheese production in Brazil is characterized by the territorial dispersion and structural difference between the processing units (Chehadi \& Vieira, 2004). There are processing units with a modern structure, which follow the international quality standards, and artisanal processing units. The great regional dispersion generates a high cost of reception, thus whey is usually treated as a waste and destined for less noble purposes. These factors may explain the reasons for the non-use of whey by all cheese producers.

Some dairy industries have been adapted for the reception and processing of this by-product from other producers. The results of this study reinforce that the dairy industries understand the importance of using whey to produce an added value product and/or minimize the environmental impacts caused by the inappropriate disposal of this by-product.

When questioned about the quality control of whey from other dairy industries, all of them claimed to perform physicochemical analyses at the reception, including $\mathrm{pH}$, temperature, stability, density, fat, and fraud investigation, which suggests that there is care with regard to the quality of the raw material received at the production unit. In fact, for the use of whey, its quality should be attested through physicochemical and microbiological analyses, once the quality of the processed product depends on the hygiene conditions of the establishment, the process control, the care with the cheese processing, and the temperature conditions during the production and storage, among others.

Milk has a high microbial load, which can affect the dairy products. The use of lactic acid bacteria in the cheese manufacture can lead to high microbiological counts in cheese whey, thus justifying the need to investigate the quality before using whey in food formulations (Mendes \& Souza, 2017), to maintain the quality and stability of the product. It was observed that the determinations reported in the questionnaires were not the same for all dairy industries, once some made more complete physicochemical and microbiological analyses while others performed basic analyses, which shows the lack of standardization among the different dairy industries.

The prevalence of sweet whey from dairy industry is intrinsically related to the type of product to be manufactured. Whereas acid whey can be used as a flavor enhancer in salad dressings, water retainer, emulsifier, among others, due to its more intense acidic and salty taste, sweet whey may be used in the preparation of bakery products, snack foods, ice creams and dairy desserts (Nishanthi et al., 2017; Fox et al., 2017).

In fact, whey dairy beverages are the products most related to the use of whey, which are considered refreshing and with a functional appeal (Guimarães et al., 2018; Mituniewicz-Małek et al., 2019). This characteristic is due to the presence of whey proteins, recognized as sources of essential amino acids, bioactive peptides, antioxidants, and immunostimulants, conferring benefits to human health (Amaral et al., 2018). Whey beverages are considered an alternative to traditional yogurts, due to its lower costs (Cappato et al., 2018). The addition of whey to dairy beverage formulations results in healthy products with high acceptability, high nutritional value, flexibility in flavoring, low investment and high utilization with respect to the amount of whey that can be added (Kelly, 2019b). The ricotta cheese, which is a white cheese with low fat content and high nutritional value, is another alternative for dairy industries to reuse whey (Mendes \& Souza, 2017). The great production of ricotta is motivated by allowing to use the same equipment necessary for the manufacture of the common cheeses (Nunes et al., 2018). The production of whey concentrate has advantages concerning the product's storage, once the product is preserved due to its low water activity, reducing storage costs. This ingredient is used in animal feed and in the preparation of confectionery as a partial or total substitute for milk powder. This substitution is advantageous due to its low fat and lactose levels, besides the improvements in the nutritional properties (Kelly, 2019a). However, it is an ingredient with a high cost of production, requiring great demand, production planning, and market strategies for compensation (Araque et al., 2018; Fusaro et al., 2019). Therefore, supermarket chains are still the main routes for the commercialization of whey-containing products.

\section{Conclusion}

This study performed an interesting diagnosis of the use of cheese whey by Brazilian dairy processors, demonstrating that the dairy industries are aware of the benefits of the addition of whey in the manufacture of new products, for economic reasons and preservation of the environment. The types of cheese produced in the country give the direction of the possible forms of use, once most cheese is produced by enzymatic coagulation, with $67 \%$ of dairy industry generating sweet whey that can be used in the formulation of whey dairy beverages, ricotta, whey concentrate and milk blends (whey and milk powder) and destined primarily for supermarket chains (53\%).

In addition, there is a market for the use of this by-product in the country, since $27 \%$ of dairy industries still do not use whey for the manufacture of other food products, resulting in less noble destinations (effluent treatment system or animal feed). Both the territorial dispersion of the dairy industries and the structural difference between the processing units impair the use of whey by the dairy industries. Although there is a concern about the quality of whey, once all dairy industries analyzed whey from other suppliers, there is still a need to standardize the determinations. 


\section{References}

Ahmad, T., Aadil, R. M., Ahmed, H., Rahman, U., Soares, B. C. V., Souza, S. L. Q., Pimentel, T. C., Scudino, H., Guimarães, J. T., Esmerino, E. A., Freitas, M. Q., Almada, R. B., Vendramel, S. M. R., Silva, M. C., \& Cruz, A. G. (2019). Treatment and utilization of dairy industrial waste: A review. Trends in Food Science \& Technology, 88, 361-372.

Amaral, G. V., Silva, E. K., Costa, A. L. R., Alvarenga, V. O., Cavalcanti, R. N., Esmerino, E. A., Guimarães, J. T., Freitas, M. Q., Sant'Ana, A. S., Cunha, R. L., Moraes, J., Silva, M. C., Meireles, M. A. A., \& Cruz, A. G. (2018). Whey-grape juice drink processed by supercritical carbon dioxide technology: physical properties and sensory acceptance. Lebensmittel-Wissenschaft + Technologie, 92, 80-86. http://dx.doi. org/10.1016/j.lwt.2018.02.005.

Araque, L. C. M., Darré, M., Ortiz, C. M., Massolo, J. F., \& Vicente, A. R. (2018). Quality and yield of Ricotta cheese as affected by milk fat content and coagulant type. International Journal of Dairy Technology, 721, 340-346.

Brasil. (2012). Regulamento de identidade e qualidade de soro de leite. Retrieved from http://www.terraviva.com.br/clique/minuta.html

Brighenti, M., Govindasamy-Lucey, S., Jaeggi, J. J., Johnson, M. E., \& Lucey, J. A. (2018). Effects of processing conditions on the texture and rheological properties of model acid gels and cream cheese. Journal of Dairy Science, 101, 6762-6775. http://dx.doi.org/10.3168/ jds.2018-14391. PMid:29753471.

Cappato, L. P., Ferreira, M. V. S., Moraes, J., Pires, R. P., Rocha, R. S., Silva, R., Neto, R. P. C., Tavares, M. I. B., Freitas, M. Q., Rodrigues, F. N., Calado, V. M. A., Raices, R. S. L., Silva, M. C., \& Cruz, A. G. (2018). Whey acerola-flavoured drink submitted Ohmic Heating: bioactive compounds, antioxidant capacity, thermal behavior, water mobility, fatty acid profile and volatile compounds. Food Chemistry, 263, 81-88. http://dx.doi.org/10.1016/j.foodchem.2018.04.115. PMid:29784332.

Carvalho, F., Prazeres, A. R., \& Rivas, J. (2013). Cheese whey wastewater: characterization and treatment. The Science of the Total Environment, 445-446, 385-396. http://dx.doi.org/10.1016/j.scitotenv.2012.12.038. PMid:23376111.

Chehadi, M. C. G., \& Vieira, J. A. G. (2004). Comportamento reológico do soro de queijo. Revista do Instituto de Latícinios Cândido Tostes, 59, 169-172.

Felicio, T. L., Esmerino, E. A., Cruz, A. G., Nogueira, L. C., Raices, R. S. L., Deliza, R., Bolini, H. M., \& Pollonio, M. A. (2013). Cheese. What is its contribution to the sodium intake of Brazilians? Appetite, 66, 84-88. http://dx.doi.org/10.1016/j.appet.2013.03.002. PMid:23500416.

Fox, P. F., Guinee, T. P., Cogan, T. M., \& McSweeney, P. L. (2017). Fundamentals of cheese science (pp. 755-769). New York: Springer. http://dx.doi.org/10.1007/978-1-4899-7681-9_22.

Fusaro, I., Giammarco, M., Chincarini, M., Odintsov, M., Andrea, V., Ludovica, F., Mammi, M. E., \& Vignola, G. (2019). Fatty acids, health indices and sensory properties of Ricotta cheese from sheep fed three different diets. International Journal of Dairy Technology, 72, 427-434.

Gomes, R. A. R., Pithan e Silva, R. O., Van Dender, A. G. F., \& Zacarchenco, P. B. (2017). O setor de produtos lácteos. In P. B. Zacarchenco, A. G. F. Van Dender \& R. A. Rego (Eds.), Brasil Dairy Trends 2020 (pp. 11-45). Campinas: ITAL.

Guimarães, J. T., Silva, E. K., Costa, A. L. R., Cunha, R. L., Freitas, M. Q., Meireles, M. A. A., \& Cruz, A. G. (2018). Manufacturing a prebiotic whey beverage exploring the influence of degree of inulin polymerization. Food Hydrocolloids, 77, 787-795. http://dx.doi. org/10.1016/j.foodhyd.2017.11.021.
Guimarães, J. T., Silva, E. K., Ranadheera, C. S., Moraes, J., Raices, R. S. L., Silva, M. C., Ferreira, M. S., Freitas, M. Q., Meireles, M. A. A., \& Cruz, A. G. (2019). Effect of high-intensity ultrasound on the nutritional profile and volatile compounds of a prebiotic soursop whey beverage. Ultrasonics Sonochemistry, 55, 157-164. PMid:30853535.

Kelly, P. (2019a). Manufacture of whey protein products: concentrates, isolate, whey protein fractions and microparticulated. In H. C. Deeth \& N. Bansal (Eds.), Whey proteins: from milk to medicine (pp. 97-122). London: Academic Press. http://dx.doi.org/10.1016/ B978-0-12-812124-5.00003-5.

Kelly, P. (2019b). Whey protein ingredient applications. In H. C. Deeth \& N. Bansal (Eds.), Whey proteins: from milk to medicine (pp. 335375). London: Academic Press. http://dx.doi.org/10.1016/B978-012-812124-5.00010-2.

Lutz, J. M., Ernst, N., Brummit, A. R., Hofman, J. C., Schweihofer, J. P., Cho, S., \& Rozeboom, D. W. (2017). 401 Feeding liquid sweet whey to growing swine. Journal of Animal Science, 95(Suppl. 2), 194. http://dx.doi.org/10.2527/asasmw.2017.401.

Mann, B., Athira, S., Sharma, R., Kumar, R., \& Sarkar, P. (2019). Bioactive peptides from whey proteins. In H. C. Deeth \& N. Bansal (Eds.), Whey proteins: from milk to medicine (pp. 519-547). London: Academic Press. http://dx.doi.org/10.1016/B978-0-12-812124-5.00015-1.

Marquardt, L., Rohlfes, A. L. B., Monte Baccar, N., Oliveira, M. S. R., \& Santos Richards, N. S. P. (2012). Indústrias lácteas: alternativas de aproveitamento do soro de leite como forma de gestão ambiental. Tecnologica, 15, 79-83.

Mendes, F. S., \& Souza, C. F. V. (2017). Qualidade microbiológica de soro de queijo e soro de ricota de laticínios do vale do Taquari, Rio Grande do Sul. Revista Brasileira de Tecnologia Agroindustrial, 11, 2437-2450.

Mituniewicz-Małek, A., Zielińska, D., \& Ziarno, M. (2019). Probiotic monocultures in fermented goat milk beverages: sensory quality of final product. International Journal of Dairy Technology, 72(2), 240-247. http://dx.doi.org/10.1111/1471-0307.12576.

Nishanthi, M., Chandrapala, J., \& Vasiljevic, T. (2017). Compositional and structural properties of whey proteins of sweet, acid and salty whey concentrates and their respective spray dried powders. International Dairy Journal, 74, 49-56. http://dx.doi.org/10.1016/j. idairyj.2017.01.002.

Nunes, L. A., Gerber, J. Z., Costa, F. P., Souza, R. J. S., \& Kalid, R. A. (2018). O soro do leite, seus principais tratamentos e meios de valorização. Revista em Agronegócio e Meio Ambiente, 11, 301-326. http://dx.doi.org/10.17765/2176-9168.2018v11n1p301-326.

Palmieri, N., Forleo, M. B., \& Salimei, E. (2017). Environmental impacts of a dairy cheese chain including whey feeding: an Italian case study. Journal of Cleaner Production, 140, 881-889. http://dx.doi. org/10.1016/j.jclepro.2016.06.185.

Smithers, G. W. (2015). Whey-ing up the options: yesterday, today and tomorrow. International Dairy Journal, 48, 2-14. http://dx.doi. org/10.1016/j.idairyj.2015.01.011.

Uduwerella, G. J., Chandrapala, J., \& Vasiljevic, T. (2018). Pre-concentration of yoghurt base by ultrafiltration for reduction in acid whey generation during Greek yoghurt manufacturing. International Journal of Dairy Technology, 71, 71-80. http://dx.doi.org/10.1111/1471-0307.12393.

Yadav, J. S. S., Yan, S., Pilli, S., Kumar, L., Tyagi, R. D., \& Surampalli, R. Y. (2015). Cheese whey: A potential resource to transform into bioprotein, functional/nutritional proteins and bioactive peptides. Biotechnology Advances, 33, 756-774. http://dx.doi.org/10.1016/j. biotechadv.2015.07.002. PMid:26165970.

Zoccal, R. (2016). Queijos: produção e importação. Retrieved from http://www.baldebranco.com.br/queijos-producao-e-importacao/ 